\title{
Yaşlılarda Kardiyovasküler Hastalıklar ve Beslenme Etmenleri
}

\author{
Cardiovascular Diseases and Nutritional Factors in Elderly
}

\section{Seda Çiftçi ${ }^{1}$, Neslişah Rakıcıoğlu ${ }^{2}$}

Geliş tarihi/Received: 28.10.2018 • Kabul tarihi/Accepted: 11.03.2019

\section{ÖZET}

Günümüzde yaşam süresinin uzamasına bağlı olarak, yaşlı nüfusunda artış gözlenmektedir. 2030 yllında dünya nüfusunun yaklaşık beşte birinin 65 yaş üzerinde olacağı öngörülmektedir. Dolayısıyla, ilerleyen yaşla beraber kardiyovasküler hastalık mortalitesi ve morbiditesindeki artış, yaşlılıkta sağlığın korunmasını ve sürdürülmesini olumsuz etkileyebilmektedir. Ülkemizde kardiyovasküler hastalık prevalansı yaşla beraber artmaktadır. Bu nedenle kardiyovasküler hastalıkların değiştirilebilir risk etmeni olan beslenmenin, yaşlının sağlığını olumlu yönde etkileyerek sağlığının sürdürülmesini destekleyecek ve özellikle kardiyovasküler hastalıklara karşı koruyacak yönde düzenlenmesi, yaşlı bireyin yaşam kalitesinin ve süresinin artışı için elzemdir. Bu derleme makalede, sağlık profesyonelleri için güncel bilgilerin ışığında yaşlı bireylerde beslenmenin, kardiyovasküler hastalıklardaki önemi ve uygulanabilecek beslenme stratejilerinin vurgulanması amaçlanmaktadır.

Anahtar kelimeler: Yaşl, kardiyovasküler hastallklar, beslenme

\begin{abstract}
Recently the elderly population is increasing due to the longevity of human life. It is forseen that by 2030 one out of five of the world's population will be over 65 years old. Therefore, cardiovascular disease mortality and morbidity increase with advancing age may adversely affect the maintenance of health in old age. The prevalence of cardiovascular disease in our country increases with age. For this reason, it is essential to modify elderly diet which is a changeable risk factor for increasing the quality of life of the elderly person in order to support the maintenance of his/her health by affecting the health of the elderly positively, and protecting against cardiovascular diseases. In this review; in the light of current information, it is aimed to emphasize the importance of nutrition in elderly people in cardiovascular diseases and nutrition strategies that can be applied for health professionals.
\end{abstract}

Keywords: Elderly, cardiovascular diseases, nutrition

1. İletişim/Correspondence: Hacettepe Üniversitesi, Sağlık Bilimleri Fakültesi, Beslenme ve Diyetetik Bölümü, Ankara, Türkiye

- E-posta: seda.ciftci@hacettepe.edu.tr

(ㄱ) https://orcid.org/0000-0002-4103-1618
2. Hacettepe Üniversitesi, Sağllk Bilimleri Fakültesi, Beslenme ve Diyetetik Bölümü, Ankara, Türkiye

๑ https://orcid.org/0000-0001-8763-7407 


\section{GíRiş}

Günümüzde yaşam süresinin uzamasına bağlı olarak her geçen gün yaşlı nüfus artmaktadır. Dünya nüfusunun yaklaşık beşte birinin 2030 yllında 65 yaşın üzerinde olacağı öngörülmektedir. İlerleyen yaşla beraber kardiyovasküler hastalıkların (KVH) prevalansı da artmaktadır (1). KVH, koroner kalp hastalığı (kalp krizi), serebrovasküler hastalıklar (inme), yüksek kan basincı (hipertansiyon), periferal arter hastalıkları, romatizmal kalp hastalığı, konjenital kalp hastalığı ve kalp yetmezliğini kapsamaktadır (2). Dünya genelinde kardiyovasküler hastalıklardan ölüm oranı 65 yaş öncesinde \%31 iken, 65 yaş sonrasında \%81'e ulaşmaktadır $(1,3)$. Ülkemizde ise Sağlık Bakanlığı'nın yürüttüğü koroner kalp hastalığı sıklığı çalışmasında, 55-64 yaş arası kadın bireylerde koroner kalp hastalığı prevalansı \%6.9, erkek bireylerde ise \%10.9 olarak bildirilmiştir. Ayrıca KVH prevalansının 65-74 yaş arasındaki kadın bireylerde \%9.3, erkek bireylerde $\% 18.3$ ve 75 yaş üzeri kadın bireylerde $\% 10.8$ erkek bireylerde \%19.6 olarak saptanmış olması, ülkemizde de kardiyovasküler hastalık prevalansının yaşla beraber arttığını ve erkeklerde kadınlardan daha sık görüldügünü göstermektedir (4). Bu derleme makalede sağlık profesyonelleri için güncel bilgilerin ışığında beslenmenin kardiyovasküler hastalıklardaki önemi ve uygulanabilecek beslenme stratejilerinin vurgulanması amaçlanmaktadır.

\section{Kardiyovasküler Hastalık Risk Etmenleri}

Kardiyovasküler hastalık riskinin ilerleyen yaşla beraber artması kontrol edilemeyen fizyolojik risk etmenidir. Yaşlanmayla beraber damarlarda endotelyum, intima ve media tabakasinda değişiklikler meydana gelmekte, endotel hücre yaşlanmakta, nitrik oksit biyoyararlanımı azalmakta ve düz kas hücreleri aktive olmaktadır. Kalp kasında hücre ölümü, hipertrofi ve fibröz oluşmaktadır (5). Dolayısıyla normal yaşlanma sürecinde kalbin ve damarların yapısı ve işlevindeki bozulma, KVH gelişimine ayrıca kroner kalp hastalığı, hipertansiyon ve kalp yetmezliğine neden olabilmektedir (6).
Böylece kaçınılmaz olan yaşlanma sürecine aşağıda belirtilen kontrol edilebilir risk etmenlerinin de eklenmesi, kardiyovasküler hastalık riskini daha kuvvetli arttırmaktadır. Kardiyovasküler hastalık risk etmenleri aşağıda verilmiştir $(7,8)$.

- İlerleyen yaş (Erkek $=\geq 55$ yaş, kadın $=\geq 65$ yaş)

- Sedanter yaşam tarzı,

- Tütün ve tütün mamulleri kullanımı,

- Beslenme bozuklukları,

- Fazla kilolu veya obez olmak,

- Prematür KVH aile öyküsü olması (Erkek <55 yaş, kadın < 65 yaş),

- Dislipidemi [total kolesterol ve düşük dansiteli lipoprotein (LDL) kolesterolü yüksek, yüksek dansiteli lipoprotein (HDL) kolesterolü düşük olmasi] durumunda kolesterol esterleri arterin intima tabakasında birikerek lezyon/yağ çizgisi oluşmasına neden olmaktadır. Eğer bu süreç devam ederse aterosklerotik plak oluşumu gerçekleşebilmektedir. İlerleyen süreçte büyüyen plak damarın içine doğru genişlerse ve/veya koparsa bu durum iskemik hastalık, koroner kalp hastalığı, iskemik inme veya periferal arter hastalığına neden olabilmektedir (9),

- Bireylerin hipertansiyon tanısı almış olması (Kan basincl >140/90 mm Hg),

- Diyabet tanısı (65 yaş ve üzeri bireylerin yaklaşık dörtte biri diyabet hastasıdır. Ayrıca diyabet tanısı almış yaşlı bireylerde prematüre ölüm, hipertansiyon, kroner kalp hastalığı ve inme gibi hastalıkların görülme oranları daha yüksektir. Dolayısıyla yaşlı bireyin diyabet tanısı mevcutsa mutlaka kan glukozu regülasyonu sağlanmalıdır (10).

- Metabolik sendrom

Belirtilen etmenlerin sağlıklı düzeylerde olması kardiyovasküler hastalıkların yaklaşık \%80'ini geciktirebilmekte veya önleyebilmektedir (1). 
Yunanistan ve ülkemizde yaşayan, Yunan asıllı 724 yaşlı birey (65-100 yaş) üzerinde yapılan bir çalışmada, kardiyovasküler risk etmenlerinden hipertansiyon, diyabet, dislipidemi ve obezite değerleri puanlanarak hesaplanmıştır. Yunan adalarında yaşayan bireylerin kardiyovasküler hastalı skorları

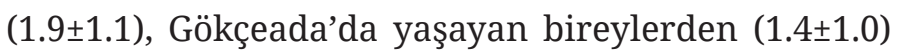
daha yüksek bulunmuştur $(\mathrm{p}<0.001)$. Bu durumun çevresel, kültürel ve yaşam tarzı farklılıklarına bağlı olabileceği belirtilmiştir. Aynı çalışmada ek olarak özellikle beslenmenin, fiziksel aktivitenin ve sigara kullanımının yaşlı bireylerin sağlıklarının korunmasında etkili olduğu vurgulanmıştır (11).

Kalp yetmezliği yaşlılıkla beraber gelişebilen ilerleyici, sağlığı kısıtlayan ve ölümle sonuçlanabilen bir hastalıktır. Yaşlanma sürecindeki değişiklikler, kardiyovasküler hastalıkların varlığı ve düzeltilmeyen risk etmenleri, yaşlılıkta kalp yetmezliği yükünü arttırabilmektedir. Yaşlanma, kardiyovasküler hastalık süreci ve kalp yetmezliği arasındaki ilişki Şekil 1'de görülmektedir (12).

Dislipidemi: Yaşam süreci içerisinde yaşla beraber kan kolesterol değeri artmaktadır. Bu artışı etkileyen etmenler, yetersiz ve dengesiz beslenme, egzersizden uzak yaşam tarzı ve genetiktir. Ancak ileri yaşla beraber kan kolesterol değeri, erkeklerde 55 yaş ve üzerinde, kadınlarda ise 65 yaş ve üzerinde azalmaya başlamaktadır. Özellikle yaşlılıkta, 85 yaş ve üzerinde, toplam kolesterol ve LDL kolesterol ile $\mathrm{KVH}$ riski arasındaki ilişki net değildir. Bu azalmanın nedeni, karaciğer işlevindeki azalmaya bağlı kolesterol sentezindeki azalmadır. LDL kolesterol düzeylerine kıyasla HDL kolesterol değeri, özellikle erkeklerde yaşla beraber daha az dalgalanma göstermektedir $(13,14)$. Ayrıca yaşlı bireylerde bağırsakta transit geçiş hızının artmış olması ve safradaki kolesterol miktarının fazla olması gibi intralüminal durumlar LDL kolesterol değerindeki artışın nedenleri arasında sayılabilir (14).

\section{Yașlanma Süreci}

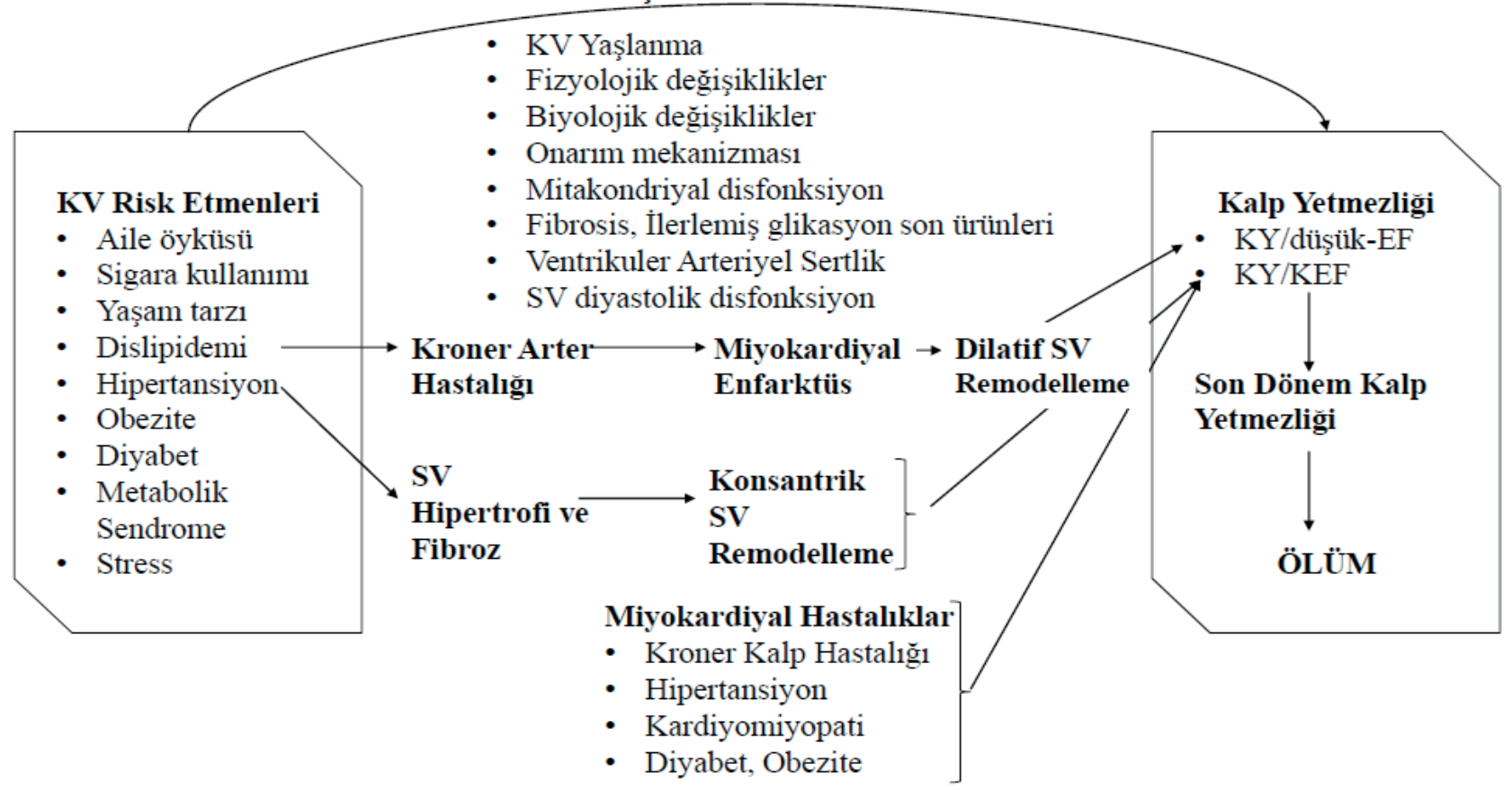

Şekil 1. Kalp yetmezliği, yaşlanma ve kalp-damar hastalıkları süreci. Kalp yetmezliği, yaşlanmayla paralel olarak ortaya çıkan ve ölüme yol açabilen ilerleyici bir hastalıktır. Yaşlanma ve kalp-damar hastalıkları sürecinde oluşan değişiklikler yaşlılarda kalp yetmezliği yükünün artmasına neden olabilir.

KV: Kardiyovasküler, EF: Ejeksiyon fraksiyonu, KY: Kalp yetmezliği, SV: Sol ventrikül, KEF: Korunmuş ejeksiyon fraksiyonu (12) 
Akdeniz diyeti, doymuş yağ asitlerinden zengin diyet ile karşılaştırıldığında periferal mononükleer kan hücrelerinde inflamatuvar genlerin ekspresyonunu azaltmaktadır. Postprandiyal evrede ise aterosklerotik plak dayanıksızlığı ile ilişkili metalloproteinlerin ekspresyonunu azaltmaktadır. Dolayısıyla Akdeniz diyetine uygun beslenme kardiyovasküler hastalık riskinin düşük olmasının bir nedeni olabilir (15).

Sonuç olarak, yaşlanmaya bağlı karşılaşılan biyolojik değişikliklerin zararlı olabilecek etkilerinden korunmak veya bu etkileri hafifletmek için beslenme en önemli değiştirilebilir risk etmenidir (16).

\section{Yaşlılıkta Kardiyovasküler Hastalıklarda Beslenme Stratejileri}

Amerikan Kalp Derneği (17) ve 2015 Beslenme Kılavuzları Danışma Komitesi'nin (18) önerileri, kardiyovasküler hastalık tanısı almış yaşlı bireyler için geçerli olup, dikkat edilmesi gereken beslenme ilkeleri aşağıda sıralanmıştır. Diyetisyenler bu ilkeler doğrultusunda kardiyovasküler hastalığı olan yaşlılarda, yaşlıya özel beslenme programını bireyin kendisiyle ve gerekli durumlarda bakımıyla ilgilenen kişi ile beraber oluşturmalıdır (19). Kardiyovasküler hastalık risk etmeni veya koruyucu olduğu düşünülen bazı besin ve besin ögeleri ile ilgili bilgiler aşağıda özetlenmiştir.

Yağ asitleri alımı: Günlük diyetimiz genellikle tekli doymamış (zeytinyağı, fındık yağı), çoklu doymamış (ayçiçek, mısırözü yağı ve balık yağı) ve doymuş yağlar (tereyağı, kuyruk yağı) olmak üzere üç yağ türünü içermektedir. Ayrıca katı margarinler çoklu doymamış yağların, hidrojen ile doyurulmasıyla elde edildiğinden kolesterol içermezler, ancak kardiyovasküler hastalık risk etmeni olan trans yağ asitlerinden zengindir. Beslenmemizde yer alan çoklu doymamış yağ asitlerinden özellikle n-3 yağ asitleri, antiinflamatuvar, anti-trombotik ve antiaterosklerotik etkilere sahip olduğu için endotel işlevi düzenleyerek, aterosklerotik plak oluşumunu geciktirir ve kardiyovasküler sağlığı olumlu etkiler (20).
Yapılan bir çalışmada, 60-80 yaş aralığında miyokart enfarktüsü (MI) öyküsü olan hastalara düşük doz günlük ortalama $376 \mathrm{mg}$ eikosapentaenoik asit (EPA) ve dokosaheksaenoik asit (DHA) veya $1.9 \mathrm{~g}$ alfa linolenik asit (18:3, ALA) verilmesinin kardiyovasküler hastalıklarda belirgin azalma sağlamadığı saptanmıştır (21). Ancak başka bir sistematik derlemede, yüksek doz n-3 yağ asidi (2-4 g/gün) kullanımının yüksek trigliserit değerini düşürmede etkili olduğu belirtilmiştir (22).

Günlük enerjinin \%20-35’inin yağlardan sağlanması, doymuş yağ ve trans yağ asidi alımının düşük tutulması, linoleik asit alımının günlük enerjinin en az \%4'ü olması, a-linolenik asit alımının günlük enerjinin en az \%0.5'i olması EPA ve DHA alımının ise günlük 250 mg olması önerilmektedir (23).

Karbonhidrat alımı: Amerikan Kalp Derneği günlük tükettiğimiz tahılların en az yarısının tam tahıllardan sağlanmasını önermektedir. 2020 önerileri için stratejik planda, posadan zengin tam tahillarin ( $\geq 1.1 \mathrm{~g}$ posa her $10 \mathrm{~g}$ karbonhidrat için) günlük $3 \mathrm{ve}$ üzeri en az 28 gramlık porsiyon olarak tüketimini önermektedir (16).

Homosistein: Homosistein düzeyinin yükselmesi vasküler hastalıklar için bağımsız risk etmenidir. Genetik etmenler (MTHFR C677T), bireysel alışkanlıklar (sigara kullanımı, kahve ve alkol tüketimi) ve beslenme $\left(B_{6}\right.$ vitamini, $B_{12}$ vitamini ve folik asidin yetersiz/düşük alımı) homosistein değerini etkileyen bireysel etmenlerdir (24). Plazma homosistein düzeyi ile folat, $B_{6}$ ve $B_{12}$ vitamini düzeyleri arasında zıt ilişki vardır. Çünkü vücudumuzda homosistein, $\mathrm{B}_{12}$ vitamininin kofaktör olarak yer aldığı remetilasyon yoluyla metiyonine, $\mathrm{B}_{6}$ vitamininin kofaktör olarak bulunduğu transsülfürasyon yoluyla da sisteine dönüşmektedir. Dolayısıyla bu vitaminlerin beslenmeyle alınmaları kardiyovasküler sağlığın korunması açısından gerekli ve önemlidir (25).

Günlük $\mathrm{B}_{6}$ vitamini gereksinimimiz 51 yaş üzeri erkek bireyler için $1.7 \mathrm{mcg}$, kadınlar için ise $1.5 \mathrm{mcg}$ olup, plazma değeri dokulardaki depoların durumunu 
yansıtması nedeniyle plazma 5 pridoksal fosfat değerinin (20 nmol/L) sürdürmesinin sağlanması amaçlanmalıdır. $\mathrm{B}_{12}$ vitamini günlük gereksinimi 51 yaş ve üzeri erkek ve kadın bireyler için 2.4 mcg'dır. Ancak, 65 yaş ve üstü bireylerde $\mathrm{B}_{12}$ vitamini eksikliği yaklaşık olarak \%12-40 arasında görülmektedir. Bu nedenle yaşlı bireylerde karşılaşılabilecek $\mathrm{B}_{12}$ vitamini emilim bozukluğuna karşı dikkatli olunmalıdır. Yeterli beslenemeyen yaşlı bireylere kristal formda $\mathrm{B}_{12}$ vitamini desteği kullanmaları önerilmektedir. Bu nedenle günlük folat gereksiniminin karşllanması, kardiyovasküler hastalıklardan korunmada önemlidir. Elli bir yaş ve üzeri kadın ve erkek bireyler için günlük folat gereksinimi 400 mcg’dır (26).

D vitamini alımı: D vitamini eksikliği yaşlılarda kardiyovasküler mortalite için bağımsız bir risk etmenidir.

Şekil 2'de aterosklerotik vasküler hastalığa neden olan D vitamini eksikliğinin mekanizması görülmektedir. Renin-anjiyotensin-aldosteron aktivitesinde, insülin direncinde ve inflamasyona neden olan parathormon düzeyindeki artışı içermektedir (27). İlerleyen yaşla beraber güneş ışığına maruziyetin azalması ve derinin $\mathrm{D}$ vitamini sentezleme kapasitesindeki azalma, yaşlılıkta D vitamini eksikliğine neden olmaktadır. Bu durumda, kan paratiroid hormon değeri normalden daha fazla artış göstererek miyokardiyal kalsifikasyona neden olmaktadır. Ayrıca D vitamini eksikliği ve/veya yetersizliği inflamasyon belirteçlerindeki artışa neden olarak ateroskleroz gelişimini tetiklemekte ve kardiyovasküler hastalık gelişimini etkilemektedir (28).

Beslenme ile D vitamini alımı, kanda 25(OH)D vitamini düzeyinin istenilen düzeye yükselmesini sağlamaz. Günlük 400 IU D vitamini desteği alınması, kan 25(OH)D vitamini değerinde, başlangiç değerine bağlı olarak 7-12 nmol/L artış sağlamaktadır. Ayrıca kan 25(OH)D vitamini değerini 50 nmol/L'den 80 nmol/L'ye yükseltmek için yaklaşık olarak günlük 1700 IU ek D vitaminine gereksinme vardır (29).

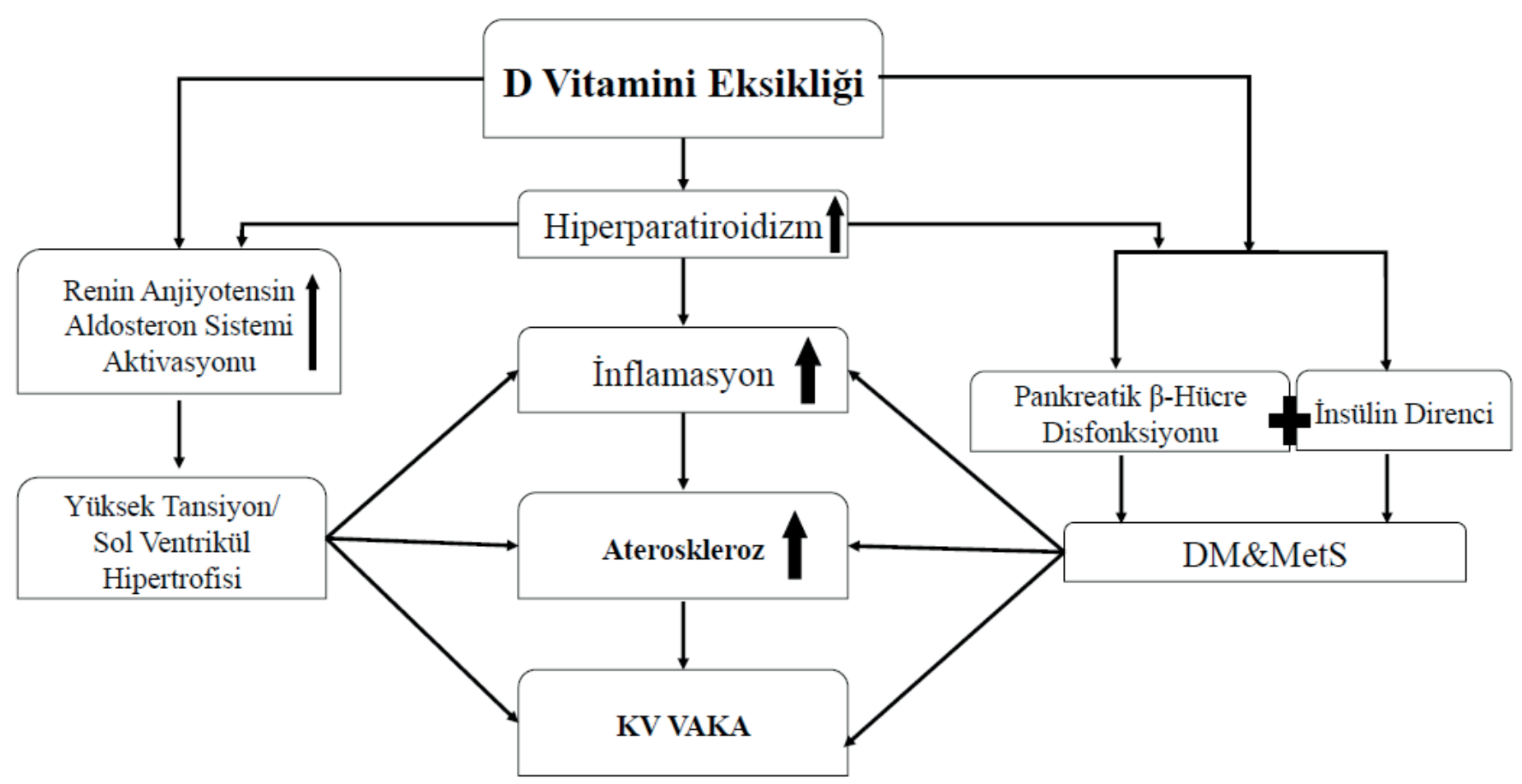

Şekil 2. D vitamini eksikliği ve kardiyovasküler hastalık riski arasındaki ilişki. D vitamini eksikliğinin mekanizmaları aterosklerotik vasküler hastalığa neden olmaktadır (27). DM: Diabetes mellitus, MetS: Metabolik Sendrom, KV: Kardiyovasküler 
Flavonoid Alımı: Flavonoidler, lipit peroksidasyonunu önleyerek aterosklerotik plakların büyümesini engeller. Yedi yll süren bir izlem çalışmasında, flavonoid alımının KVH'lardan ölüm riskini azalttığı saptamıştır. Bu nedenle az da olsa flavonoid içeren besinlerin tüketilmesinin kardiyovasküler sağlık açısından yararlı olduğu bildirilmiştir (30). Prospektif kohort çalışmalarının meta analizinde, flavonoidlerin (flavonoller, antosiyanidinler, pro-antosiyanidinler, flavonlar, flavanonlar ve flavan-3-oller) alınması ile KVH riski arasında ters ilişki saptanmıştır. Flavonoid alımının artması KVH riskini azaltmıştır (31).

Soya tüketimi: Gıda ve İlaç Dairesi (Food and Drug Administration, FDA), 1999 yllında soya içeren besinlerin etiketlerine KVH'lara karşı koruyucu olduğu ibaresinin yazılabileceğini onaylamıştır. Ayrıca, FDA besinin etiketinde KVH'lara karşı koruyucu olduğu ibaresinin yer alabilmesi için, o besinin bir porsiyonunun günlük alınması gereken soya proteini miktarını $(25 \mathrm{~g})$ dörtte birini (6.25 g) içermesini ve günde en az 4 kez tüketilebilmesi gerektiğini belirtmektedir (32). Yapılan randomize paralel kontrollü bir çalışmada, 60-70 yaş arasında kadın bireyler üç farklı gruba ayrılarak, on iki hafta boyunca izlenmişlerdir. Birinci grup günlük $35 \mathrm{~g}$ soya fistığı, ikinci grup günlük $35 \mathrm{~g}$ işlenmiş soya proteini tüketirken, son grup kontrol grubu olarak ayrılmıştır. Başlangıçta ve on ikinci hafta sonunda bireylerin toplam kolesterol, TG, HDL, LDL, çok düşük dansiteli lipoprotein (VLDL) kolesterolü, ApoB100, ApoAI, C-reaktif protein (CRP) ve fibrinojen değerleri kaydedilmiştir. Soya fistığı tüketen grubun LDL, VLDL ve ApoB100 değerleri belirgin olarak düşük bulunmuştur. Serum toplam kolesterol değerinin kontrol grubuna kiyasla müdahale gruplarında belirgin olarak azaldığı görülmüştür $(\mathrm{p}<0.05)$. Soya proteinlerinin lipit profilini iyileştirdiği, soya fıstığı tüketenlerde işlenmiş soya proteini tüketenlere kıyasla daha fazla iyileşme olduğu gözlemlenmiştir (33).

Çay tüketimi: Flavonoidlerin bir alt sınıfı olan flavan-3-ollerden zengin bitkisel besinlerin [kakao
(Theobroma cacao), çay (Camellia Sinensis) ve elmalar] tüketimi ile kardiyovasküler hastalık riski arasında ters ilişki vardır. Yapılan bir çalışmada, beslenmeyle epikateşin alımının kardiyovasküler mortalitesi ile ilişkisi Flemenk yaşlı erkekler ( $n=774$, yaş=65-84) üzerinde 25 yll süreyle araştırılmıştır. Koroner kalp hastalığı mortalite riski, günlük $22 \mathrm{mg}$ epikateşin [6 bardak siyah çay ( 1 bardak $=125 \mathrm{~mL}$ ) veya $54 \mathrm{~g}$ siyah çikolata (\%54 kakao içeren) ve 2-3 elma (1 elma=120 g)] tüketen bireylerde, daha az miktarda epikateşin tüketen ( $7.9 \mathrm{mg} /$ gün) bireylere kıyasla $\% 38$ oranında düşük bulunmuştur. Ayrıca epikateşin alımı kardiyovasküler hastalığı olan yaşlı erkek bireylerde kardiyovasküler mortaliteyi \%46 oranında azaltırken, kardiyovasküler hastalığı olmayan bireylerde etkisi görülmemiştir (34).

Süt ve süt ürünleri tüketimi: Rotterdam çalışmasında, 55 yaşüstü $(n=4235)$ bireylerin yaklaşık 17 yıllık izlemi sonucunda süt ve süt ürünlerinin (az yağlı/yağlı süt ürünleri, süt, fermente süt ürünleri, peynir, yoğurt) yüksek miktarda tüketimi $(>400$ g/gün) ile düşük miktarda tüketimi (<200 g/gün) karşılaştırıldığında, kardiyovasküler hastalık veya inme riski ile ilişki bulunmuştur (35).

Sebze ve meyve tüketimi: Prospektif çalışmaların sistematik derlemesi ve doz-yanit meta-analizinde, yüksek oranda sebze ve meyve tüketiminin kardiyovasküler hastalık mortalitesi ile ters ilişkili olduğu saptanmıştır. Çalışmanın sonuçları da kardiyovasküler sağlığın sürdürülmesi ve korunması için günlük beş porsiyon sebze veya meyve tüketimi önerisinidesteklemektedir. Beslenmeyeeklenengünlük bir porsiyon meyve kardiyovasküler hastalık riskini $\% 6$, bir porsiyon sebze ise $\% 5$ oranında azaltmaktadır. Ancak aynı çalışmada günlük beş porsiyondan fazla sebze ve meyve tüketiminin kardiyovasküler hastalık riskini daha fazla düşürmediği de eklenmiştir (36).

Tuz tüketimi: Yüksek tuz tüketimi yüksek kan basıncı ile ilişkili olup, tuz tüketiminin azaltılması kan basıncında belirgin azalma sağlanmaktadır. Tip Enstitüsü Besin ve Beslenme Kurulu, yaşlllıkta karşılaşılan böbrek hastalıkları veya diyabet gibi 
tıbbi sorunların vücudun sodyum düzeyini dengede tutabilmesini sinırlayabileceğinden 51-70 yaş arasındaki bireylerin günlük 1.3 gram sodyum (yarım çay kaşığı) ve 71 yaş üzeri bireylerin ise günlük 1.2 gram sodyum tüketmelerini önermektedir (37).

Alkol tüketimi: Orta ve hafif derecede alkol tüketiminin kardiyovasküler yararları yaşlılarda gözlenmekte olup, özellikle kırmızı şarap HDL kolesterol düzeyini arttırmakta, LDL kolesterol ve plazma fibrinojen düzeyini düşürmekle birlikte platelet birikimini azaltmaktadır. (38). Mukamal ve arkadaşlarının yürüttüğü kohort çalışmada (39), 65 yaş üzerinde ve 9.2 yıldır kardiyovasküler hastalığ olmayan bireylerde $(\mathrm{n}=4410)$ alkol tüketimi ile aterosklerotik kardiyovasküler hastalıklar arasındaki ilişki araştırılmıştır. Haftada 14 kez ve üzerinde alkollü içecektüketenbireylerde,hiçalkollüiçecektüketmeyen bireylere kıyasla yeni gelişen koroner kalp hastalığ görülme oranı belirgin olarak düşük bulunmuştur. $\mathrm{Bu}$ sonuç yaş, cinsiyet, ırk, beden kütle indeksi (BKI), diyabet öyküsü, tütün ve tütün mamulleri kullanımı, aspirin kullanımı, yapılan egzersizin yoğunluğu, depresyon skoru, medeni durum ve eğitim durumuna göre düzeltmeler yapıldıktan sonra da değişmemiştir (39). Uzunlamasına, prospektif ve nüfus tabanlı yapılan bir çalışmada, 65 yaş ve üstü [n=5256, 2318 alkol kullanmayan, 2309 hafif ile orta düzeyde alkol kullanan ( $\leq 2$ alkol birimi/gün)] bireyler altı yıl süreyle izlenmiştir. Ilımlı alkol tüketiminin, fiziksel aktivite ve sağlık durumundan bağımsız olarak kardiyovasküler mortaliteyi etkilemediği bulunmuştur. Ilımlı alkol tüketimi günlük $113 \mathrm{~mL}$ şarap veya $340 \mathrm{~mL}$ bira veya $42.5 \mathrm{~mL} \% 80$ alkol içeren (viski, votka, likörler vb.) alkollü içecekleri içermektedir (40).

\section{SONUÇ VE ÖNERILER}

Günümüzde kardiyovasküler hastalıklar özellikle yaşlılarda morbiditesi ve mortalitesi yüksek bir hastalı grubudur (13). Bu hastalıkların, değiştirilebilir risk etmenlerine karşı yapılacak mücadele ile engellenebileceği ya da hafifletilebileceği belirtilmektedir. Değiştirilebilir risk etmenlerinden biri olan beslenmenin, özellikle risk altındaki bireylerde kardiyovasküler hastalık morbiditesi ve mortalitesi ile mücadelede etkin olduğu yapılan çalışmalarla gösterilmektedir. $\mathrm{Bu}$ nedenle, $\mathrm{KVH}$ riski taşıyan yaşlıların beslenme rehberlerinin ışı̆̆ında oluşturulan bireye özel koruyucu beslenme programlarını edinmeleri ve uygulamaları, yaşam kalitelerinin artmasında olumlu etki sağlayacaktır.

Çıkar çatışması - Conflict of interest: Yazarlar çıkar çatışması olmadığını beyan ederler. - The authors declare that they have no conflict of interest.

\section{KAYNAKLAR}

1. Oh JY, Allison MA, Barrett-Connor E. Different impacts of hypertension and diabetes mellitus on all-cause and cardiovascular mortality in community-dwelling older adults: the Rancho Bernardo Study. J Hypertens. 2017;35(1):55-62.

2. Third Report of the National Cholesterol Education Program (NCEP) Expert Panel on Detection, Evaluation, and Treatment of High Blood Cholesterol in Adults (Adult Treatment Panel III) final report. Circulation. 2002;106(25):3143-421.

3. Jackson CF, Wenger NK. Cardiovascular disease in the elderly. Rev Esp Cardiol (Engl Ed). 2011;64(8):697-712.

4. Türkiye Kronik Hastalıklar ve Risk Faktörleri Sıklığı Çalışması. Sağlık Bakanlığı Yayın. No: 909. Ankara, 2013.

5. North BJ, Sinclair DA. The intersection between aging and cardiovascular disease. Circ Res. 2012;110(8):1097108.

6. Costa E, Santos-Silva A, Paul C, Gonzalez Gallego J. Aging and cardiovascular risk. Biomed Res Int 2015;2015:2.

7. Giles TD, Materson BJ, Cohn JN, Kostis JB. Definition and classification of hypertension: an update. J Clin Hypertens 2009;11(11):611-4.

8. Guo F, Garvey WT. Trends in Cardiovascular Health Metrics in Obese Adults: National Health and Nutrition Examination Survey (NHANES), 1988-2014. J Am Heart Assoc. 2016;5(7).

9. Yahagi K, Davis HR, Joner M, Virmani R. Atherosclerosis, 
Introduction and Pathophysiology. In: Jagadeesh G, Balakumar P, Maung-U K, editors. Pathophysiology and Pharmacotherapy of Cardiovascular Disease. Cham: Springer International Publishing; 2015. p. 527-46.

10. American Diabetes Association. Older adults. Standards of medical care in diabetes-2017. Diabetes Care 2017;40(Suppl. 1):99-104

11. Foscolou A, Polychronopoulos E, Paka E, Tyrovolas S, Bountziouka V, Zeimbekis A, et al. Lifestyle and health determinants of cardiovascular disease among Greek older adults living in Eastern Aegean Islands: An adventure within the MEDIS study. Hellenic J Cardiol. 2016.

12. Jugdutt BI. Heart failure in the elderly: advances and challenges. Expert Rev Cardiovasc Ther. 2010;8(5):695715.

13. Bell SP, Rich MW. Cardiovascular Disease. In: Burton JR, Lee AG, Potter JF, editors. Geriatrics for Specialists. Cham: Springer International Publishing; 2017. p. 24367.

14. Félix-Redondo FJ, Grau M, Fernández-Bergés D. Cholesterol and cardiovascular disease in the elderly. Facts and gaps. Aging Dis. 2013;4(3):154.

15. Camargo A, Delgado-Lista J, Garcia-Rios A, Cruz-Teno C, Yubero-Serrano EM, Perez-Martinez P, et al. Expression of proinflammatory, proatherogenic genes is reduced by the Mediterranean diet in elderly people. Br J Nutr. 2012;108(3):500-8.

16. Rippe JM, Angelopoulos TJ. The Role of Nutrition and Lifestyle in the Prevention and Treatment of Cardiovascular Disease. In: Rippe JM, editor. Nutrition in Lifestyle Medicine. Cham: Springer International Publishing; 2017. p. 137-50.

17. Lichtenstein AH, Appel LJ, Brands M, Carnethon M, Daniels S, Franch HA, et al. Diet and lifestyle recommendations revision 2006: a scientific statement from the American Heart Association Nutrition Committee. Circulation. 2006;114:82-96.

18. Dietary Guidelines Advisory Committee. Scientific Report of the 2015 Dietary Guidelines Advisory Committee: Advisory Report to the Secretary of Health and Human Services and the Secretary of Agriculture. U.S. Department of Agriculture, Agricultural Research Service, Washington, DC.

19. Dorner B, Friedrich EK. Position of the Academy of Nutrition and Dietetics: Individualized nutrition approaches for older adults: long-term care, postacute care, and other settings. J Acad Nutr Diet.
2018;118(4):724-35.

20. Mozaffarian D. Dietary and policy priorities for cardiovascular disease, diabetes, and obesity. A comprehensive review. Circulation. 2016;133(2):187225.

21. Kromhout D, Giltay EJ, Geleijnse JM. n-3 fatty acids and cardiovascular events after myocardial infarction. N Engl J Med. 2010;2010(363):2015-26.

22. Jain A, Aggarwal K, Zhang P. Omega-3 fatty acids and cardiovascular disease. Eur Rev Med Pharmacol Sci. 2015;19(3):441-5.

23. EFSA Panel on Dietetic Products Nutrition Allergies. Scientific Opinion on Dietary Reference Values for fats, including saturated fatty acids, polyunsaturated fatty acids, monounsaturated fatty acids, trans fatty acids, and cholesterol. EFSA Journal. 2010;8(3).

24. Refsum H, Nurk E, Smith AD, Ueland PM, Gjesdal CG, Bjelland I, et al. The Hordaland Homocysteine Study: a community-based study of homocysteine, its determinants, and associations with disease. J Nutr. 2006;136(6):1731-40.

25. Kuller LH, Evans RW. Homocysteine, vitamins, and cardiovascular disease. Circulation. 1998;98(3):196-9.

26. Institute of Medicine Standing Committee on the Scientific Evaluation of Dietary Reference Intakes. Dietary Reference Intakes For Thiamin, Riboflavin, Niacin, Vitamin $\mathrm{B}_{6}$, Folate, Vitamin $\mathrm{B}_{12}$, Pantothenic Acid, Biotin, And Choline. Washington: National Academies Press (US); 1998.

27. Harikrishnan S, Sanjay G. Vitamin D and cardiovascular disease - Have we found the answers? Indian Heart J. 2015;67(1):11-3.

28. Fleg JL, Forman DE, Berra K, Bittner V, Blumenthal JA, Chen MA, et al. Secondary prevention of atherosclerotic cardiovascular disease in older adults: A scientific statement from the American Heart Association. Circulation. 2013;128(22):2422-46.

29. Vieth R, Bischoff-Ferrari H, Boucher BJ, Dawson-Hughes B, Garland CF, Heaney RP, et al. The urgent need to recommend an intake of vitamin $\mathrm{D}$ that is effective. Am J Clin. Nutr. 2007;85(3):649-50.

30. McCullough ML, Peterson JJ, Patel R, Jacques PF, Shah R, Dwyer JT. Flavonoid intake and cardiovascular disease mortality in a prospective cohort of US adults. Am J Clin Nutr. 2012;95(2):454-64.

31. Wang X, Ouyang YY, Liu J, Zhao G. Flavonoid intake and risk of CVD: a systematic review and meta-analysis of 
prospective cohort studies. Br J Nutr. 2014;111(1):1-11.

32. Hasler CM. Functional foods: benefits, concerns and challenges-a position paper from the American Council on Science and Health. J Nutr. 2002;132(12):3772-81.

33. Bakhtiary A, Yassin Z, Hanachi P, Rahmat A, Ahmad Z, Jalali F. Effects of soy on metabolic biomarkers of cardiovascular disease in elderly women with metabolic syndrome. Arch Iran Med. 2012;15(8):462-8.

34. Dower JI, Geleijnse JM, Hollman P, Soedamah-Muthu SS, Kromhout D. Dietary epicatechin intake and 25-y risk of cardiovascular mortality: the Zutphen Elderly Study. Am J Clin Nutr. 2016;104(1):58-64.

35. Praagman J, Franco OH, Ikram MA, Soedamah-Muthu SS, Engberink MF, van Rooij FJ, et al. Dairy products and the risk of stroke and coronary heart disease: the Rotterdam Study. Eur J Nutr. 2015;54(6):981-90.

36. Wang X, Ouyang Y, Liu J, Zhu M, Zhao G, Bao W, et al. Fruit and vegetable consumption and mortality from all causes, cardiovascular disease, and cancer: systematic review and dose-response meta-analysis of prospective cohort studies. BMJ. 2014;349:g4490.

37. Institute of Medicine. 2005. Dietary Reference Intakes for Water, Potassium, Sodium, Chloride, and Sulfate. Washington, DC: The National Academies Press; 2004.

38. Kalla A, Figueredo VM. Alcohol and cardiovascular disease in the geriatric population. Clin Cardiol. 2017;40(7):444-9.

39. Mukamal KJ, Chung H, Jenny NS, Kuller LH, Longstreth WT Jr, Mittleman MA, et al. Alcohol consumption and risk of coronary heart disease in older adults: the Cardiovascular Health Study. J Am Geriatr Soc. 2006;54(1):30-7.

40. Muscari A, Bianchi G, Conte C, Forti P, Magalotti D, Pandolfi P, et al. No direct survival effect of light to moderate alcohol drinking in community-dwelling older adults. J Am Geriatr Soc. 2015;63(12):2526-33. 